\title{
Islam Dan Sinkretisme Di Jawa
}

\author{
Masyhudi
}

Keywords: assimilation, diffusion, culture, islam, java

\section{How to Cite:}

Masyhudi, nfn. (2003). Islam Dan Sinkretisme Di Jawa. Berkala Arkeologi, 23(1), 8895. https://doi.org/10.30883/jba.v23i1.863

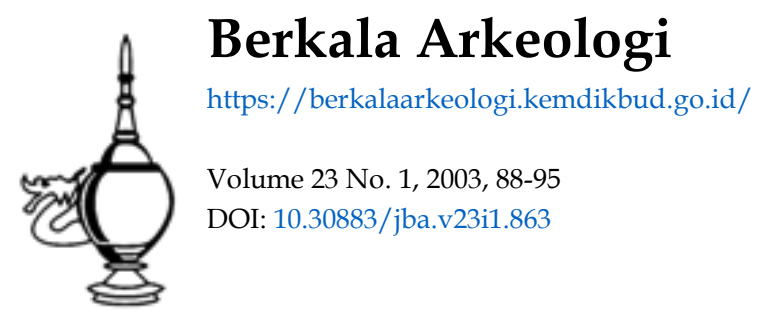

\section{c) (1) (5)}

This work is licensed under a Creative Commons Attribution-NonCommercial-ShareAlike 4.0 International License. 


\title{
ISLAM DAN SINKRETISME DI JAWA
}

\author{
Masyhudi
}

\section{$\mathbf{P}$} endahuluan

Pulau Jawa merupakan bentang lahan yang berada pada posisi yang sangat menguntungkan, yaitu posisi yang dapat membawa dampak akumulasi kultural dan politik yang datang dari berbagai arah. Hubungan yang terus-menerus antara Pulau Jawa dengan pulau-pulau lain yang berakibat terjadinya akulturasi, yaitu menyerap tradisi dari berbagai negeri yang sering berkomunikasi dengan Pulau Jawa.

Sejak datangnya Islam di Nusantara yang ditandai dengan berbagai tinggalan arkeologis, baik yang bersifat monumental maupun yang non monumental, diantaranya sebuah makam kuna (tertua) yang terdapat di Gresik, yaitu makam Fatimah Binti Maimun, dengan kronologi yang menunjuk angka tahun 1082/1102 M, adalah suatu bukti adanya hubungan antara Jawa dengan negeri lain.

Islam masuk ke Nusantara secara sistematis sejak abad ke-14 Masehi, berpapasan dengan suatu kebudayaan besar yang telah menciptakan suatu sistem politik, nilainilai estetika, dan kehidupan sosial keagamaan yang sangat maju yang dikembangkan oleh kerajaan-kerajaan Hindu-Budha diJawa (Geertz, 1968).

Berkembangnya Islam di Pulau Jawa secara umum, baik di daerah pesisir utara Jawa, maupun di beberapa daerah di pedalaman atau pegunungan dilakukan melalui berbagai setrategi pendekatan yang ditempuh oleh para tokoh penyebar Islam (para wali, ulama, maupun tokoh-tokoh lokal. Strategi tersebut meliputi; perdagangan, perkawinan, pendidikan, praktek-praktek sinkretisme dan mistisisme yang merupakan aktualisasi dari ajaran-ajaran tasawwuf. Strategi tersebut dilakukan sesuai dengan tuntutan suasana, artinya memasukkan ajaran-ajaran Islam kepada masyarakat dengan memperhatikan kondisi sosial-budaya yang ada, sehingga kehadiran Islam dapat diterima dengan baik, tanpa adanya perlawana ataupun konflik.

Sementara itu sinkretisme yang kental dan pengaruh ajaran mistik dari Persia pada saat itu telah mewujudkan corak Islam Asia Tenggara yang agak berbeda dengan yang diajarkan oleh nabi Muhammad saw. Disamping itu juga perkembangan ajaran 1slam yang semakin terpecah-pecah ke dalam sekte-sekte juga ikut mempengaruhi formasi masyarakat Islam di Indonesia karena hal tersebut juga berpengaruh pada corak birokrasi dan penerapan hukum Islam. 


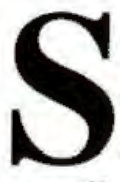
osialisasi Islam di Jawa

Sosialisasi Islam di Indonesia berlangsung secara bertahap, meskipun antara satu tempat dengan tempat yang lain berbeda, yaitu tumbuhnya komunitas muslin, baik di daerah pantai maupun di daerah pedalaman. Dalam proses tersebut, perkembangan politik, ekonomi dan panggilan agama ikut tampil sebagai motivator yang ikut menentukan corak, penyebaran, pengembangan dan bentuk masyarakat muslim di setiap daerah tempat terjadinya sosialisasi. Di Jawa, proses tersebut berawal dari sepanjang pesisir utara yang pada waktu itu berperan sebagai jalur lalu-lintas perdagangan internasional dan sekaligus sebagai pusat penyebaran Islam.

Awal-mula terjadinya proses sosialisasi Islam di Jawa adalah diprakarsai oleh orangorang alim dan ahli di bidang agama Islam (para wali), dan para ahli agama yang tergolong ulama. Mereka tidak hanya datang dan menetap di kota-kota tetapi juga masuk ke daerah-daerah pedalaman, sehingga pada akhirnya proses persebaran Islam berkembang tidak hanya di kota-kota tetapi juga di daerah-daerah pedalaman atau daerah pegunungan. Meskipun demikian, proses yang ditempuh oleh para tokoh penyebar Islam tersebut tidak mudah serta memakan waktu yang cukup panjang, dimana pada masa pemerintahan sultan-sultan Demak dan masa pemerintahan Sultan Agung Mataram yang secara aktif melancarkan proses sosialisasi Islam, penuh dengan tantangan dan harus dilakukan secara bertahap.

Pada sekitar abad-14 Masehi, di Jawa telah memperlihatkan bukti kuatnya mengenai peranan masyarakat muslim, terutama di daerah pesisir utara. Hal ini terbukti dengan hadirnya makam-makam kuna di Troloyo yang berangka tahun 1290 Caka (1368/1369 M), dan sekaligus sebagai bukti kemungkinan adanya masyarakat muslim di dekat pusat kerajaan Majapahit. Kemudian sejak abad-15 dan permulaan abad-16 Masehi, di beberapa daerah pusat perdagangan, yakni di Gresik, Demak, Cirebon dan Banten telah menunjukkan adanya kegiatan keagamaan yang diprakarsai oleh para wali di Jawa. Sementara itu pada pertengahan abad-16 Masehi, Demak yang pada waktu itu sebagai penguasa Islam di Jawa telah menaklukkan majapahit, dan kemudian sejak itulah perkembangan Islam di Jawa dapat berperan secara politis, yaitu para wali dan tokoh-tokoh penyebar Islam telah dibantu oleh Demak dan kemudian Mataram dapat mensosialisasikan Islam, tidak saja di daerah-daerah penting di Jawa, tetapi tetapi juga daerah-daerah di pedalaman atau pegunungan di Jawa, termasuk daerah-daerah Jawa bagian selatan.

Kemudian pada sekitar abad-17 - 18 Masehi, di Jawa telah terjadi pergulatan antara para penyebar Islam; pedagang, musafir dan ulama dan kaum sufi yang dampaknya semakin diakuinya peranan mereka dalam struktur komunitas pribumi, sehingga para tokoh tersebut dapat menduduki jabatan dalam struktur birokrasi kerajaan. Hal ini tentunya tidak terlepas dari strategi dakwah Islam yang dilakukan oleh para tokoh penyebar Islam tersebut, sehingga mereka dapat melakukan dakwah secara langsung 
kepada raja dan keluarganya, mendirikan masjid, mendidik kader ulama, serta pendekatan-pendekatan sosial yang sesuai dengan kondisi masyarakat setempat, (Ambary, 1998).

Pada abad-19 -20 yang dikenal sebagai puncak abad imperialisme merupakan masa keemasan bagi bangsa-bangsa yang bernafsu membentuk kekaisaran. Pada waktu itu Inggris, Prancis, dan bangsa-bangsa yang lain merajalela di Afrika dan Asia dengan mengancam negara-negara merdeka untuk dijadikan sebagai daerah kekuasaannya. Sementara itu Belanda jauh sebelumnya telah memulai politik ekspansinya. Namun di Indonesia, Belanda menghadapi kenyataan bahwa sebagian besar penduduk di kepulauan Nusantara yang dijajahnya adalah beragama Islam. Sementara itu Belanda merasa optimis untuk bisa secepatnya mengikis pengaruh Islam melalui kristenisasi. Hal ini didasarkan pada anggapan bahwa Islam di Indonesia, khususnya Jawa yang memang kuat sinkritismenya akan mudah penaklukannya.

\section{I}

\section{slam dan Sinkretisme di Jawa}

Secara ideologis, Islam telah meninggalkan Al-Qur'an dan As-Sunnah, sedangkan secara fisik telah memperlihatkan unsur-unsur budaya Islam sebagai unsur-unsur budaya yang berkesinambungan dari unsur-unsur budaya pada masa sebelumnya sebagai langkah adaptasi untuk mencapai hasil yang maksimal (Ambary, 1991).

Sikap adaptasi yang tercermin pada unsur-unsur budaya yang berkesinambungan tersebut dapat dilihat pada tata-cara pemakaman Islam di Jawa, dimana gunung merupakan tempat yang dianggap suci, sehingga pola penempatan bagi seorang tokoh yang paling dihormati ditempatkan di bagian paling tinggi. Demikian halnya dengan bangunan masjid yang berfungsi sebagai tempat melayani segala bentuk kegiatan keagamaan adalah bersifat dogmatis, religius, serta merupakan tuntunan pelaksanaan ajaran Islam yang berhubungan dengan konsekuensi ummat sebagai muslim. Hal ini menunjukkan bahwa kebudayaan manusia bukanlah basa-basi yang pelaksanaannya hanya formalitas semata, tetapi di dalamnya mengandung berbagai pengertian daripada fungsi masjid, yaitu masjid sebagai tempat ibadah, masjid sebagai tempat pertemuan antara manausia dengan nur ilahi, masjid sebagai kegiatan sosial, ekonomi dan lain sebagainya, (Rochym, 1983).

Suatu hal yang menjadi pertanyaan, bagaimana cara agama Islam telah berhasil masuk sampai ke pedalaman dan menyususn jaringanya. Hal yang paling mendasar yang mempengaruhi suatu daerah tempat terjadinya sosialisasi Islam adalah faktor ajaran Islam. Karena dalam hal ini telah didasari dengan suatu konsep yang berasal dari al-Qur'an, surat An-Nakhl, ayat 125; 
Serulah manusia kepada jalan Tuhanmu dengan hikmah dan pelajaran yang baik dan dan berbantahlah dengan cara yang baik pula. Sesungguhnya Dia-lah Tuhanmu yang lebih mengetahui siapa yang tersesat dari jalan-Nya dan Dialah yang lebih mengetahui orang-orang yang mendapat petunjuk, (QS, An-Nakhl : 125).

Ayat tersebut menggambarkan tentang cara (sikap yang bijaksana) Islam dalam upaya pengembangannya.

Berbagai teori tentang masuknya Islam di Jawa dan umumnya di Indonesia telah banyak dibicarakan. Akan tetapi diantara yang lebih menarik yang berkaitan dengan kebudayaan Islam di Indonesia adalah tasawwuf dan keunggulan agama Islam. Tentang tasawwuf dikatakan, bahwa Islam yang demikian dapat tersebar luas ke kepulauan nusantara adalah karena kegiatan yang dilakukan oleh para sufi. Sementara itu mengenai keunggulan daripada agama Islam sebagaimana dikatakan oleh Sayed Naquib Al-Atas, bahwa Islam segera tersebar di kalangan penduduk Indonesia terutama lapisan bawah dan menengah adalah karena daya tarik ajarannya, yaitu tentang persamaan dan persaudaraan antara sesama, dan hal ini berbeda dengan ajaran agama Hindu yang membeda-bedakan manusia menurut kasta, (Al-Atas, Sayed Naquib, 1972).

Dalam sosialisasi Islam yang awal mulanya diprakarsai oleh para wali dan secara umum daerah-daerah yang dijadikan sebagi obyek Islamisasi adalah Jawa bagian utara (daerah pantai utara Jawa) yang bertepatan pada waktu itu daerah-daerah pantai utara Jawa sangat cocok dan dominan untuk dunia perdagangan, sehinggan strategi sosialisasi Islam yang dominan diterapkan pada saat itu adalah melalui perdagangan. Akan tetapi setelah kehidupan perdagangan orang Jawa mengalami kehancuran akibat upaya Belanda memonopoli perdagangan dan orang-orang Islam pada saat itu tidak dapat memainkan peran penting dalam percaturan politik di kota-kota, maka tindak lanjut penyebaran Islam ini digunakan setrategi dalam bentuk yang lain, yaitu melalui pendidikan di desa-desa (daerah-daerah pedalaman) Jawa, bahkan sampai di beberapa daerah di pegunungan selatan Jawa. Dalam fase ini bukan lagi peran para wali, tetapi sudah dilanjutkan oleh para tokoh ulama atau kyai dengan mendirikan masjid, surau ataupun pesantren di beberapa daerah pedalaman Jawa bagian selatan. Hal ini dapat dibuktikan melalui beberapa tinggalan arkeologi dan sejarah yang diduga kuat merupakan sisa aktivitas masyarakat di masa lalu, yaitu berupa makam, masjid, bekas bangunan pesantren dan naskah-naskah kuna, (Masyhudi, 2000).

Disamping itu proses sosialisasi Islam di Jawa, secara ideal bersumber kepada alQur'an dan Sunnah rasulullah saw. Akan tetapi awal mula proses Islamisasi di Jawa ini melalui berbagai tradisi lisan dan babad-babad yang sebagaian besar dari babadbabad yang ada menempatkan para wali (walisongo) yang hidup pada sekitar abad-16 Masehi pada posisi pertama dalam peran Islamisasi di Jawa. Operasional para wali tersebut sebagian besar di daerah-daerah Jawa bagian utara. Sedangkan upaya 
islamisasi di beberapa daerah di pedalaman dilakukan oleh mubaligh penerus para wali (orang-orang saleh) yang datang dari pesisir masuk ke pedalaman dengan satu tujuan, yaitu mengislamkan penduduknya. Diantara tokoh tersebut adalah Ki Gede Pandanaran atau dikenal dengan Sunan Bayat, (Lombard, 1996).

Sosialisasi Islam yang telah berlangsung sejak beberapa abad yang lalu adalah bermula pada kegiatan para wali yang kesemuanya pengikut suatu aliran mistik yang amat jelas coraknya. Meskipun dalam peng-Islaman di tanah Jawa merupakan sederetan peristiwa yang sangat kompleks, namun Islam di daerah ini mampu memampatkan suatu periode panjang dari sebuah kerajaan besar, yaitu Majapahit, (Grunebaum, 1983 : 339). Sehingga sejak (akhir abad-15), Islam telah menggantikan Hinduisme di Jawa, yaitu dengan munculnya kerajaan Demak sebagai kerajaan terkuat di tanah Jawa dan merupakan senjata utama dalam kegiatan politik, dan pada akhimya sebagian besar masyarakat Jawa telah dapat di Islamkan (Dhofier, 1984).

Selain itu, dakwah Islamiah yang dilakukan oleh para tokoh terdahulu juga dengan menggunakan lambang-lambang budaya dan lembaga pendidikan, sedangkan pendekatan yang digunakan dalam misi tersebut adalah pendekatan sinkretis, yaitu memanfaatkan lambang-lambang budaya dan lembaga lembaga yang ada kemudian diisi dengan muatan-muatan ajaran Islam, sehingga mudah dicerna dan diterima oleh masyarakat awam.

Masalah sinkritisme Islam di Indonesia, terutama di Jawa memang cukup banyak disoroti. Snouck Hurgronje menyatakan, bahwa Orang Islam di kawasan ini sebenarnya hanya nampaknya saja memeluk Islam dan hanya dipermukaan kehidupan mereka ditutupi oleh agama ini, ibarat berselimutkan kain yang penuh dengan lobanglobang besar sehingga di dalamnya nampak keasliannya, bahkan pada akhir abad-20, mayoritas masyarakat Jawa adalah abangan, yaitu hidupnya tidak sesuai dengan tuntunan formal agama, (Niels Mulder, 1983).

Namun hal yang lebih penting adalah bahwa betapapun sinkretis dan abangannya masyarakaat Jawa adalah mereka tetap muslim, bahkan dalam kondisi demikian agama Islam merupakan kekuatan dinamik pagi masyarakat Jawa yang sebagian besar sebagai petani (hidup di daerah agraris).

Dalam proses sinkretisasi ini, tidak hanya berlangsung pada bidang kognitif, tetapi juga pada tingkat perilaku, dan inipun akan dipandang sebagai sesuatu hal yang wajar, jika dipandang atau ditafsirkan melalui kacamata sinkretik.

Sebagai contoh yang dikisahkan dalam babad tanah Jawi; bahwa kehadiran Nyai Rara Kidul, yang banyak diyakini oleh sebagian masyarakat Jawa sebagai makhluk halus, ternyata tidak menolak berhubungan dengan raja Jawa (Panembahan Senopati) atas 
bimbingan Sunan Klijaga, sebagai seorang tokoh yang akan menetapkan Islam sebagai agama di Jawa. Dari sini dapat kita tarik suatu tafsir bahwa Islam dan pra Islam dapat bersatu dengan Jawa. Dalam konteks ini, relasi antara Panembahan senopati dengan Nyai Rara Kidul dapat dipandang sebagai elemen pra Islam (Jawa) dan di pihak lain Sunan Kalijaga sebagai elemen Islam.

Contoh yang lain adalah munculnya konsep Ratu Adil dan harapan akan datangnya hari keemasan pada paertengahan abad-18 Masehi. Konsep tersebut muncul merupakan cerminan dari masyarakat yang telah lama mengalami penindasan dan penderitaan, sebagai dampak dari penjajahan Kolonial Belanda. Menurut Th.G.Th. Pigeaud, di Jawa banyak beredar risalah-risalah yang mengajarkan tentang akan datangnya imam Mahdi, dalam kaitannya dengan waktu menjelang hari kiamat yang dalam bahasa Jawa dikenal dengan istilah Kabar Kiamat. Kemudian pada abad-18 sampai dengan abad-19 muncul perpaduan dari unsur-unsur dalam kabar kiamat dengan ramalan Jayabaya, dam kemudian pada abad-19 harapan akan datangnya Imam Mahdi muncul dimana-mana dan risalah-risalah yang berisi tentang akan datang hari kiamat dan juru selamat menjadi populer.

Kata Imam Mahdi berasal dari kata Imam yang berarti pemimpin, khalifah atau ratu (Kepala Negara) dan Mahdi berarti orang yang mendapat petunjuk dari Tuhan. Dalam ajaran Syi'ah, Imam Mahdi adalah calon ratu adil atau pemimpin umat yang mendapat petunjuk Tuhan.. Kedatangannya sangat dinanti-nantikan, untuk mengatur dunia dengan adil dan makmur serta menghukum orang-orang yang dzalim dan durhaka.

Sisa-sisa pengaruh Syi'ah sampai sekarang masih terdapat di beberapa daerah di Jawa, misalnya perayaan bulan Asyura (10 Muharam) yang biasanya dirayakan dengan sajian nasi bubur sampai sekarang masih diadakan di kampung-kampung di beberapa daerah di Jawa. Perayaan ini dimaksudkan untuk mengenah Imam Husein (cucu nabi Muhammad) yang mati terbunuh pada perang Karbala pada tahun 680 Masehi.

Di Jawa, mengenai ajaran tentang akan datang Imam Mahdi banyak disampaikan oleh guru-guru tarekat. Sedangkan ajaran tentang akan datangnya Ratu Adil dengan zaman keemasan disampaikan melalui perantaraan Serat-Jayabay. Nama Ranggawarsita Sangat dikagumi dan digemari oleh masyarakat karena kepandaian belau sebagai peramal. Ranggawarsita melukiskan zaman keemasan bahwa orang-orang yang duduk sambil mengantuk saja akan mendapat kethuk, dan kethuk semacam itu terdapat di jalanjlan (dimana-mana), orang yang mendapatkannya menjadi bersuka cita, karena di dalamnya berisi emas,dan permata yang gemerlapan. Gambaran tentang zaman keemasan yang menyertai datangnya Ratu adil atau Imam Mahdi tersebut adalah suatu hal yang sangat menarik bagi masyarakat yang telah lama megalami penderitaan, sehingga merupakan sesuatu yang wajar jika hal tersebut banyak diminati dan sangat diharapkan oleh masyarakat. 
Dalam hal ini Sartono berpendapat, bahwa Sinkretisme yang memberi cap kepada unsur-unsur kebudayaan Indonesia nyebabkan perlambang Jayabaya menjadi susunan capuran anatara mitologi dan kosmologi Hindu -Mahdisme dalam Islam yang berkembang di Jawa, (Sartono, 1971).

Jika kita perhatikan, proses sinkretisasi antara budaya Islam dan Jawa, dapatlah kita lihat bahwa sinkretisasi dapat berjalan mulus, karena berada pada tatanan simbolis. Hal semacam ini telah dilakukan oleh para tokoh penyebar Islam di masa lalu, sehingga dengan cara demikian, sinkretisasi Jawa dan Islam dapat berjalan terus, demikian juga budaya Jawa dan Islam akan selalu relevan dengan kehidupan sehari-hari.

\section{$\mathbf{K}$}

\section{esimpulan}

Jawa adalah merupakan pulau yang relatif cukup besar dan padat dalam kehidupan beragama tidaun sebagian besar lahannya bercorak agraris. Tetapi terdapat di beberapa daerah di Jawa.

Proses sosialisasi Islam di Jawa berawal dari daerah pesisir utara yang diprakarsai oleh para tokoh penyebar Islam yang dikenal dengan sebut Walisongo. Proses tersebut berkembang ke beberapa daerah di pedalaman Jawa (termasuk beberapa daerah di pegunungan selatan Jawa), namun pada periode ini telah diperankan oleh para tokoh generasi penerus walisongo yang masih tergolong ulama atau kiai yang betul-betul memiliki pengetahuan keislaman yang luas dan mendalam serta memiliki keahlian dalam menentukan setrategi pengembangannya.

Setrategi yang diterapkan oleh para tokoh penyebar Islam, di daerah pesisir utara Jawa berbeda dengan setrategi yang diterapkan di beberapa daerah di pedalaman Jawa, yaitu strategi perdagangan merupakan langkah yang dominan, disamping juga dilakukan dengan pendidikan, perkawinan dan mengadopsi kesenian lokal dengan dimasuki muatan-muatan Islam. Akan tetapi pada periode berikutnya setrategi yang dominan diterapkan oleh para tokoh penyebar Islam di beberapa daerah pedalaman Jawa adalah melalui pendidikan dengan lembaga-lembaga seperti pesantren dan organisasi-organisasi tarekat yang merupakan aktualisasi dari ajaran-ajaran tasawwuf. Meskipun demikian, telah berlangsung suatu proses sinkretisasi yang menitik beratkan pada aspek kognitif dan aspek perilaku masyarakat jawa, sebagai akibat adanya dua budaya (pra-Islam dan Islam) yang saling bersentuhan, kemudian diolah sedemikian rupa sehinga tidak terjadi adanya pertentangan atau konflik. Dan pada akhirnya Islam dapat diterima oleh sebagian besar masyarakat Jawa. 


\section{KEPUSTAKAAN}

Al-Atas, Sayed Naquib, 1972. Islam Dalam Sejarah dan Kebudayaan Melayu, UKM, Kuala Lumpur.

Ambary, Hasan Muarif, 1991. Makam-Makam Kesultanan dan Para Wali Penyebar Islam di Pulau Jawa, Aspects of Indoneian Archaeology, No.12, Jakarta.

Dhofier, Zamakhsyari, 1984. Tradisi Pesantren, LP3ES, Jakarta.

Geertz, 1968. Islam Observer, New Haven and London, Yale University Press.

Grunebaum, Gustave E. Von, 1983. Islam, Kesatuan Dalam Keragaman, Yayasan Perkhidmatan, Jakarta.

Lombard, Denys, 1996. Nusa Jawa Silang Budaya, Jaringan Asia, II, Gramedia, Pustaka Utama, Jakarta.

Masyhudi, 2000. Sosialisasi Islam di Kawasan Pegunungan Selatan Jawa, Laporan Penelitian Arkeologi, Yogyakarta.

Niels Mulder, 1983. Abangan Javanese Religious Thought and Practice.

Rachym, Abdul, 1983. Masjid Dalam Karya Arsitektur Nasional Indonesia, Angkasa, Bandung.

Sartono,Katodirdjo, 1971. Missianisme dan Millenarisme dalam sejarah Indonesia, Lembaran sejarah, No. 7, (Fak.Sastra dan Kebudayaan) Universitas Gadjah Mada, Yogyakarta 